\title{
PENGARUH EFESIENSI, EFEKTIFITAS ASSETS TERHADAP LEVERAGE DAN DAMPAKNYA TERHADAP RETURN SAHAM PADA PERUSAHAAN SEKTOR PERTAMBANGAN BATU BARA YANG TERDAFTAR DI BURSA EFEK INDONESIA PERIODE TAHUN 2009-2014
}

\section{THE INFLUENCE OF EFFICIENCY, EFFEKTIVENESS OF ASSETS ON LEVERAGE AND ITS IMPACT ON STOCK RETURNS ON COAL MINING SECTOR COMPANIES LISTED ON THE STOCK EXCHANGE INDONESIA PERIOD 2009 - 2014}

\author{
M.M.Melani \\ Program Studi Akuntansi Fakultas Ekonomi Universitas Djuanda Bogor \\ Jl. Tol Ciawi No. 1, Kotak Pos 35, Kode Pos 16720, Telp/Fax : (0251) 8245155 \\ E-mail: mariamagdalenamelani2@gmail.com
}

\begin{abstract}
This research is aims to analyze the influence of efficiency, effektiveness of assets on leverage and its impact on stock returns on coal mining sector companies listed on the stock exchange Indonesia period 2009-2014. This research used purposive sampling method and obtain research samples as many as 9 companies doing an IPO on the Stock Exchange. Methods of analysis of research data using descriptive statistics for the description of the object of research, simultaneous test methods ( $F$ test) to assess the assumptions of multiple regression equations, and to test hypotheses using sub model of structure 1 test and sub model of structure 2 test. The test results showed simultaneous NPM, TATO, and DER has a significant effect on stock exchange. In Partial NPM significant positive effect on stock exchange, DER significant negative effect on stock exchange, and NPM significant negative effect on DER.
\end{abstract}

Keywords : Stock Exchange, Debt of Equity Ratio, Net Profit Margin, and Total Asset Turn Over

\begin{abstract}
ABSTRAK
Penelitian ini bertujuan untuk melakukan analisis pengaruh efesiensi, efektifitas assets terhadap leverage dan dampaknya terhadap return saham pada perusahaan sektor pertambangan batu bara yang terdaftar di Bursa Efek Indonesia periode tahun 2009-2014. Penelitian ini menggunakan metode purposive sampling dan memperoleh sampel penelitian sebanyak 9 perusahaan yang terdaftar di Bursa Efek Indonesia. Metode analisis penelitian data menggunakan statistik deskriptif untuk deskripsi obyek penelitian, metode uji simultan (Uji F) untuk menilai persamaan regresi berganda, dan untuk uji hipotesis menggunakan uji model sub struktur 1 dan sub struktur 2 .

Hasil pengujian menunjukkan secara simultan NPM, TATO dan DER memiliki pengaruh signifikan terhadap return saham. Secara Parsial NPM berpengaruh positif signifikan terhadap return saham, DER berpengaruh negatif signifikan terhadap return saham, dan NPM berpengaruh negatif signifikan terhadap DER.
\end{abstract}

Kata kunci : Return Saham, Debt of Equity Ratio, Net Profit Margin, dan Total Asset Turn Over 


\section{PENDAHULUAN}

Perusahaan sektor pertambangan batubara di Indonesia mengalami naik turun dalam proses produksi. Faktor penyebab utama adalah harga batu bara yang rendah sehingga memukul industri tersebut di tanah air. Asosiasi Pertambangan Batu Bara Indonesia (APBI) mencatat sekitar 40 persen tambang batu bara di Indonesia telah menghentikan kegiatan produksi sekitar 1 tahun ini sejak tahun 2014. Salah satu penyebab harga batu bara turun adalah pasokan batubara di pasar nasional yang melimpah sejak pertumbuhan batubara di Indonesia meningkat mencapai $10-15$ persen dalam kurun waktu 5 tahun terakhir. Dalam informasi yang dihimpun melalui web http://www.sahamok.com/grafik-harga

komoditi/batubara/ dalam kurun 5 tahun terakhir menunjukkan penurunan harga batu bara dari tahun ke tahun, untuk nilai tertinggi dicapai di tahun 2011 dengan harga \$140 per ton dan terus menurun hingga saat ini berharga $\$ 64$ per ton.

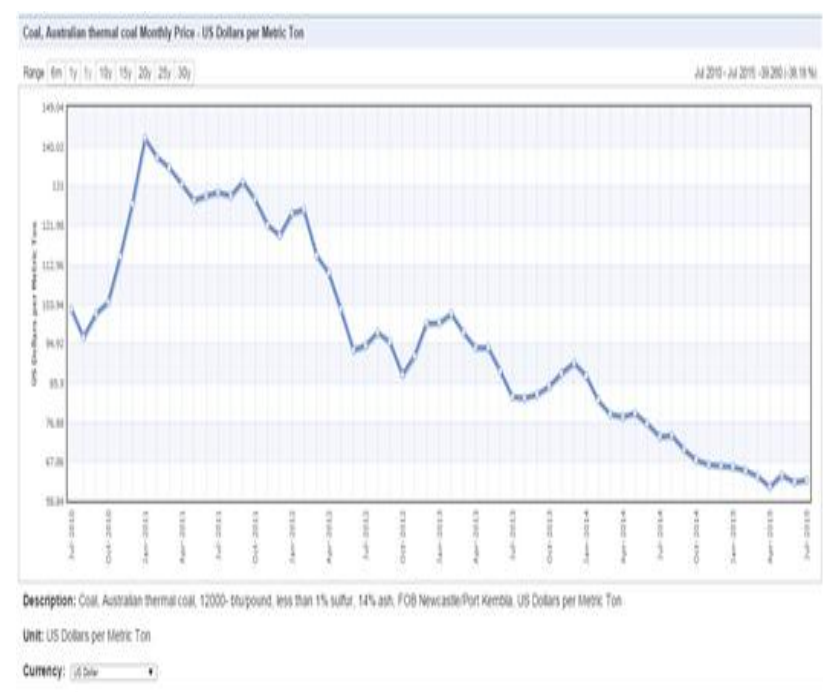

Gambar 1.1 Grafik harga batu bara per metrik ton

Dalam kurun waktu 2 tahun terakhir produksi batu bara naik dari 350 juta ton menjadi 420 juta ton, sedangkan permintaan dari Negara-negara luar berkurang. Pelemahan perusahaan pertambangan batu bara diharapakan sudah bangkit kembali sejak kementerian ESDM merekomendasikan 49 perusahaan untuk mengekspor batu bara dan terdaftar di Kementrian Perdagangan dan semakin banyaknya permintaan. Pemerintah juga akan berencana membangun pembangkit listrik tenaga uap yang menggunakan batubara sebagai bahan bakarnya dan diperkirakan akan menyerap 60 persen dari hasil pertambangan dan sisanya akan di ekspor. Kementerian ESDM juga mengumumkan akan membangun 14 pelabuhan khusus batu bara untuk menekan ekspor batubara illegal ke luar negeri. Beberapa keputusan yang diambil pemerintah akan meningkatkan permintaan batu bara yang meningkat dan tentunya akan meningkatkan pendapatan dari perusahaan dan meningkatkan nilai perusahaan.

Nilai perusahaan merupakan persepsi investor terhadap perusahaan yang sering dikaitan dengan harga saham. Harga saham yang tinggi akan membuat nilai perusahaan juga tinggi. Kenaikan harga saham akan berpengaruh terhadap return saham yang akan menarik banyak investor untuk berinvestasi dalam perusahaan. Memaksimalkan nilai perusahaan sangat penting bagi perusahaan, karena dengan memaksimalkan nilai perusahaan akan memaksimalkan kemakmuran pemegang saham yang merupakan tujuan utama perusahaan. Menurut Suad Husnan dan Enny Pudjiastuti (2002: h.7) "Nilai perusahaan merupakan harga yang bersedia dibayar oleh calon pembeli apabila perusahaan tersebut dijual". Sedangkan pengertian nilai perusahaan menurut Agus Sartono (2001: h.487) "Nilai perusahaan adalah nilai jual sebuah perusahaan sebagai suatu bisnis yang sedang beroperasi". Nilai perusahaan adalah persepsi para investor untuk menentukan tingkat keberhasilan perusahaan dalam menjalankan usahanya dan berdampak pada harga saham perusahaan. Apabila nilai perusahaan tinggi maka harga saham juga akan ikut tinggi dan dengan nilai perusahaan yang tinggi akan meningkatkan kepercayaan para investor dalam berinvestasi karena kinerja perusahaan dan juga prospek perusahaan dimasa depan.

Perusahaan pertambangan batu bara merupakan perusahaan yang memiliki nilai kapitalis pasar yang terbesar di sektor industri pertambangan yang terdaftar dalam Bursa Efek Indonesia. Mengingat saat ini harga BBM yang naik turun yang mengakibatkan mesinmesin pembangkit yang membutuhkan BBM sebagai penggerak akan mengalami peningkatan pengeluaran dalam perusahaan. Dengan memiliki alam Indonesia yang kaya akan sumber daya alam, khususnya batubara yang dapat digunakan sebagai bahan bakar untuk pembangkit listrik tenaga uap 
diharapkan permintaan akan batu bara akan meningkat sehingga akan meningkatkan kinerja perusahaan dan akan berdampak positif untuk meningkatkan nilai perusahaan. Dari hasil pengumpulan data melalui yahoo finance didapatkan hasil penurunan harga saham gabungan perusahaan sektor pertambangan batubara sebagai berikut:

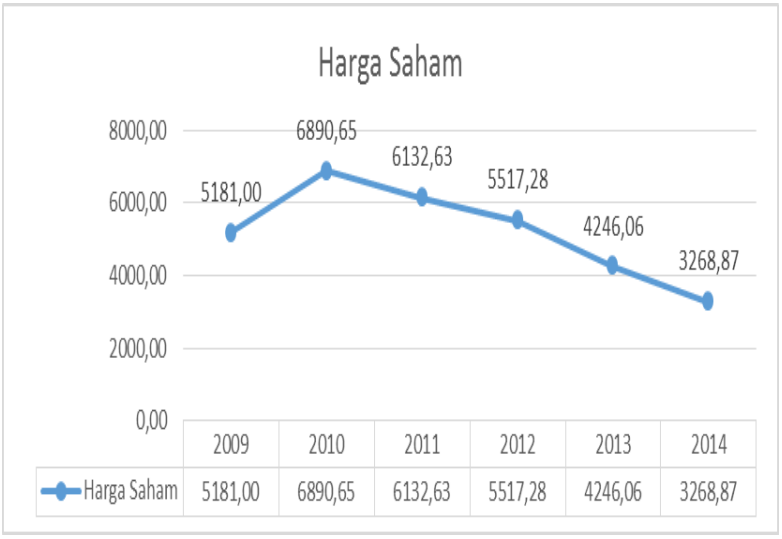

Sumber : data diolah

Gambar 1.2 Grafik penurunan harga saham gabungan perusahaan sektor pertambangan batu bara dari tahun 2009 - 2014

Jika ditinjau dari penjelasan data di gambar dalam kurun 5 tahun ini harga saham perusahaan batu bara semakin menurun dari tahun ke tahun, jumlah penurunan harga saham. Pada tahun 2009 harga saham gabungan sektor pertambangan batu bara adalah Rp. 5181. Pada tahun 2010 harga saham gabungan sektor pertambangan batu bara adalah Rp. 6890,65 meningkat Rp. 1709,65 dari tahun sebelumnya. Pada tahun 2011 harga saham gabungan sektor pertambangan batubara adalah Rp. 6132,63 menurun Rp. 758,02 dari tahun sebelumnya. Pada tahun 2012 harga saham gabungan sektor pertambangan batu bara adalah 5517,28 menurun Rp. 615,35 dari tahun sebelumnya. Pada tahun 2013 harga saham gabungan sektor pertambangan batu bara adalah Rp. 4246,06 menurun Rp. 1271,22 dari tahun sebelumnya dan pada tahun 2014 harga saham gabungan sektor pertambangan batubara adalah Rp. 3268,87 menurun Rp. 977,19 dari tahun sebelumnya. Dengan demikian return saham sektor pertambangan tersebut mengalami defisit, bukan capital gain yang namun capital loss yang didapat dari harga saham sektor tersebut .
Saham adalah selembar kertas yang menyatakan kepemilikanya atas sebagian dari perusahaan, Menurut H.M Jogiyanto (2000: h.8) harga saham adalah "Harga saham yang terjadi di pasar bursa pada saat tertentu yang ditentukan oleh pelaku pasar dan ditentukan oleh permintaan dan penawaran". Sedangkan menurut Agus Sartono (2001: h.9) "Harga saham terbentuk di pasar modal dan di tentukan oleh beberapa faktor seperti laba per lembar saham, rasio laba terhadap harga per lembar saham, tingkat bunga bebas risiko yang diukur dari tingkat bunga deposito pemerintah". Harga saham yang tidak menentu ,tentu akan membuat return saham yang tidak stabil, oleh sebab itu dilakukan analisis fundamental perusahaan dengan indikator pengukuran kinerja keuangan. Indikator yang sering digunakan adalah rasio profitabilitas. Pada penelitian ini rasio yang digunakan adalah rasio profitabilitas untuk variabel efisiensi melalui Net profit Margin (NPM).

Sedangkan menurut Bastian dan Suhardjono (2006: h.299) "Net Profit Margin adalah perbandingan antara laba bersih dengan penjualan". Semakin besar NPM maka kinerja perusahaan akan semakin produktif dan efisiensi biaya, sehingga akan meningkatkan kepercayaan investor untuk menanamkan modalnya pada perusahaan tersebut. Pada dasarnya Net Profit Margin mengukur persentasi dari penjualan setelah dikurangi dengan seluruh biaya. Semakin tinggi rasio ini maka akan semakin baik profitabilitas perusahaan.

Untuk efektifitas asset, rasio yang digunakan adalah rasio aktivitas melalui rasio Total Assets Turn Over (TATO) yang merupakan perbandingan antara total penjualan dengan total aktiva sehingga efektifitas dalam penggunaan aset akan terlihat dengan rasio tersebut. Menurut Syamsuddin, (2009: h.19) "Total Assets Turn Over merupakan rasio yang menunjukkan tingkat efisiensi penggunaan keseluruhan aktiva perusahaan dalam menghasilkan volume penjualan tertentu. "Oleh sebab itu TATO merupakan rasio yang menggambarkan perputaran aktiva diukur dari volume penjualan. Semakin besar rasio ini, maka semakin baik yang berarti bahwa aktiva dapat lebih cepat berputar dan meraih laba yang menunjukkan semakin efektifitas penggunaan keseluruhan aset dalam menghasilkan laba penjualan". 
Untuk rasio leverage atau hutang rasio yang digunakan adalah Debt to Equity Ratio (DER) yang membandingkan jumlah hutang terhadap ekuitas dengan cara menggambarkan sampai sejauh mana modal pemilik dapat menutupi hutang-hutang kepada pihak luar dan merupakan rasio yang mengukur hingga sejauh mana perusahaan dibiayai dari hutang yang mengukur seberapa bagus struktur permodalan perusahaan. Semakin tinggi angka DER maka diasumsikan perusahaan memiliki risiko yang semakin tinggi terhadap likuiditas perusahaannya.

Pada penelitian sebelumnya yang dilakukan oleh Agustine Permatasari (2012) yang menguji NPM, ROA dan ROE pada sektor pertambangan yang tercantum pada indeks LQ45 mendapatkan hasil Net Profit Margin (NPM) tidak berpengaruh terhadap return saham pada perusahaan pertambangan. Return On Assets (ROA)berpengaruh terhadap return saham pada perusahaan pertambangan dan Return On Equity (ROE) tidak berpengaruh terhadap return harga saham pada perusahaan. Pada penelitian Wahid $\mathrm{Al}$ Hayat(2014) yang berjudul Pengaruh Rasio Keuangan Terhadap Return Saham dengan variabel Rasio keuangan Current ratio (CR), Total Assets Turnover (TATO), Debt to Equity Ratio (DER), Return on Assets (ROA), dan Earning per Share (EPS) terhadap return saham pada sektor pertambangan menunjukan Current Ratio (CR) tidak berpengaruh terhadap return saham, Total Assets Turn Over (TATO) berpengaruh terhadap return saham, Debt to Equity Ratio (DER) tidak berpengaruh terhadap return saham, Return on Assets (ROA) berpengaruh terhadap return saham, dan Earning per Share (EPS) tidak berpengaruh terhadap return saham.

\section{METODE PENELITIAN}

Pada penelitian ini dilakukan dari tahun 2009 sampai dengan 2014, sektor yang diambil adalah sektor pertambangan sub sektor batubara dari perusahaan-perusahaan terbuka (Tbk) yang terdaftar di Bursa Efek Indonesia (BEI). Daftar perusahaan dalam penelitian ini diperoleh dari media internet dengan sumber

linkhttp://www.sahamok.com/emiten/sekto r-pertambangan/sub-sektor-

pertambangan-batubara/. Dari seluruh perusahaan yang berjumlah 22 perusahaan hanya 9 perusahaan yang digunakan untuk penelitian ini dikarenakan syarat penelitian perusahaan harus sudah IPO minimal dari tahun 2009 sampai 2014 serta memiliki data yang lengkap dan melaporkan laporan keuangan perusahaan ke BEI.

\section{Variabel Penelitian}

Dalam penelitian ini variabel dependen adalah return saham dan debt of equity ratio (DER), yaitu :

$$
\text { Debt to Equity Ratio }=\frac{\text { Total Debt }}{\text { Total Equity }}
$$

Dimana :

Total Debt : Total Hutang (hutang lancar dan

$$
\text { hutang jangka panjang) }
$$

Total Equity : total modal

Variabel independen adalah variabel yang mempengaruhi variabel dependen. Variabel independen dalam penelitian ini adalah :
1. $\quad N P M=\frac{\text { Lababersih setelah pajak }}{\text { Penjualan }}$
2. Total Asset TurnOver $=\frac{\text { Total Penjualan }}{\text { Total Aktiva }}$

\section{HASIL DAN PEMBAHASAN}

Uji Simultan (Uji F)

Pengujian secara simultan digunakan untuk mengetahui nilai yang memberikan kuatnya pengaruh atau hubungan dua variabel atau lebih secara bersama-sama. Kita dapat menguji secara simultan apakah regresi berganda yang telah didapatkan secara bersama-sama berpengaruh terhadap return saham atau tidak ada pengaruh. Adapun hasil pengujian secara simultan / uji F statistik dilakukan dengan model sub struktur 1 dan model sub struktur 2 sebagai dasar dalam pengujian hipotesis yang dapat dilihat pada Tabel berikut :

Tabel 1 : Uji Simultan (Uji F) 
Uji Simultan pengaruh NPM dan TAT 0 terhadap DER pada industri

pertam bangan batubara periode $2010 \cdot 2014$

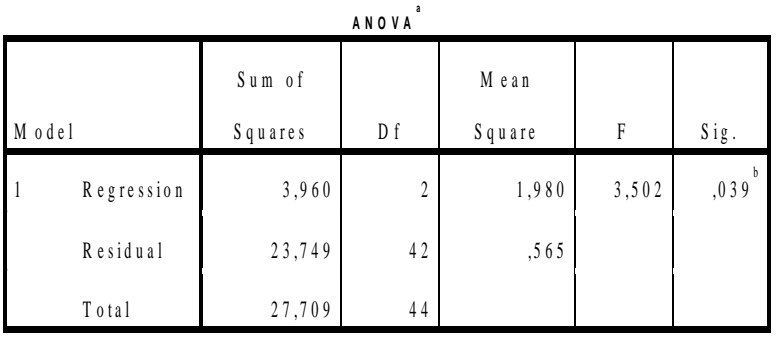

a. Dependent Variable: DER

b. Predictors: (Constant), TA T 0, NPM

Pengujian secara bersama-sama dilakukan untuk mengetahui pengaruh langsung secara bersama-sama antara NPM (X1) dan TATO (X2) terhadap DER (Y). Berdasarkan hasil yang diperoleh dari perbandingan $\mathrm{F}$ hitung dengan $\mathrm{F}$ tabel adalah $\mathrm{F}$ hitung $3.502>$ F tabel 3.1274 dengan tingkat signifikansi F sig $0.039<0.05$, maka dapat disimpulkan bahwa pada perusahaan sektor pertambangan pada periode 2010 -2014, variabel NPM dan TATO berpengaruh signifikan terhadap DER.

Tabel 2 : Uji Simultan (Uji F)

Uji Simultan pengaruh NPM, TATO dan DER terhadap return saham pada

industri pertambangan batubara periode 2010-2014

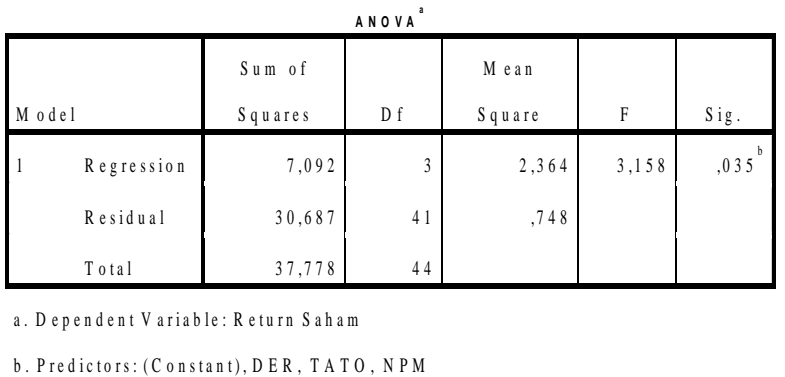

Pengujian secara bersama-sama dilakukan untuk mengetahui pengaruh langsung secara bersama-sama antara NPM (X1), TATO (X2) dan DER (Y) terhadap Return Saham (Z). Berdasarkan hasil yang diperoleh dari perbandingan $F$ hitung dengan $F$ tabel adalah Ho ditolak karena: F hitung 3.158 > F tabel 3.1274 dengan tingkat signifikansi adalah Ho diterima karena : F sig $0.035<0.05$, maka dapat disimpulkan bahwa pada perusahaan sektor pertambangan pada periode 2010 2014, variabel NPM, TATO dan NPM berpengaruh signifikan terhadap Return Saham.

\section{Pengujian Hipotesis}

Data hasil analisis dalam pengujian model sub struktur 1 dan model sub struktur 2 digunakan sebagai dasar dalam pengujian hipotesis pada penelitian ini. Penjelasan pengujian hipotesis selengkapnya diuraikan pada Tabel 5 sub struktur 1 .

Tabel 3 : Sub Struktur 3

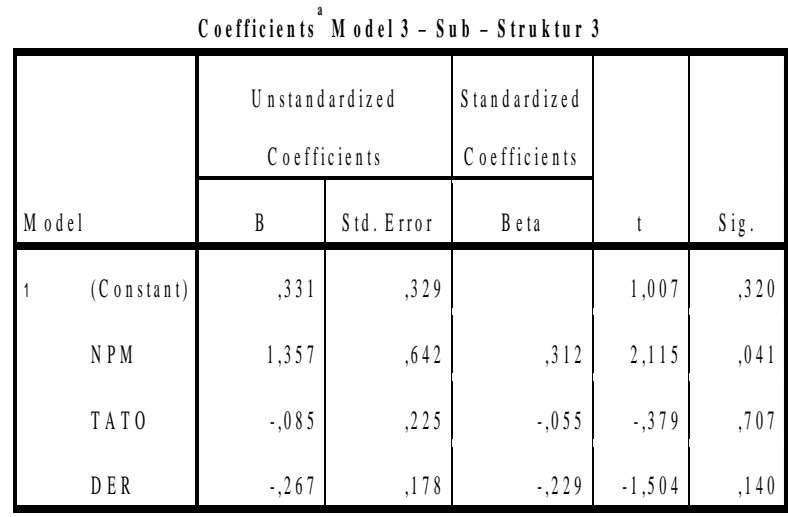

a. Dependent Variable: Return Saham

\section{Pengaruh Langsung NPM terhadap Return Saham.}

Berdasarkan hasil analisis koefisien jalur dapat diketahui bahwa NPM $\left(\mathrm{X}_{1}\right)$ berpengaruh langsung positif terhadap terhadap Return Saham (Z) dengan koefisien jalur $\beta_{41}=0,312$ dan t hitung NPM 2,115 dengan signifikansi $\alpha$ sebesar 0,05 maka signifikasi $\mathrm{t}<\alpha$ yang menujukan NPM berpengaruh 31,2 \% terhadap return saham. Oleh sebab itu apabila NPM meningkat maka Return Saham akan meningkat.

\section{Pengaruh Langsung TATO terhadap Return Saham}

Berdasarkan hasil analisis koefisien jalur dapat diketahui bahwa TATO $\left(\mathrm{X}_{2}\right)$ tidak berpengaruh langsung positif terhadap terhadap Return Saham (Z) dengan koofisien beta $\beta_{41}=-0,123$ dengan tingkat signifikan $t_{\text {hitung }}$ TATO terhadap return saham adalah $-1,076$ dengan signifikansi $\alpha$ sebesar 0,288 maka sehingga TATO tidak berpengaruh terhadap return saham.

Tabel 4 : Sub Struktur 2 


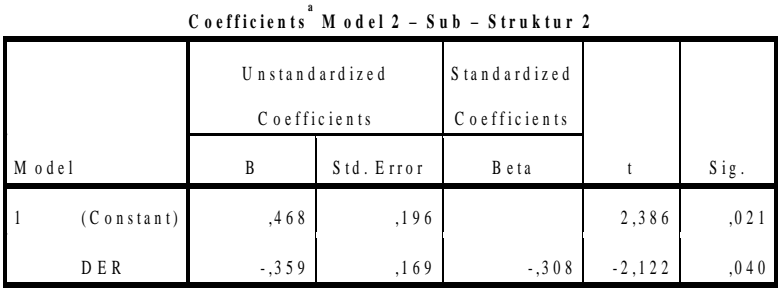

a. Dependent Variable: Return $S$ aham

\section{Pengaruh Langsung DER terhadap Return Saham}

Berdasarkan hasil analisis koefisien jalur dapat diketahui bahwa DER (Y) berpengaruh langsung negatif terhadap terhadap Return Saham (Z) dengan memiliki pengaruh langsung negatif pada koefisien jalur $\beta_{43}=$ 0,308 . Hal ini berarti apabila DER menurun maka return saham akan meningkat.

Tabel 5 : Sub Struktur 1

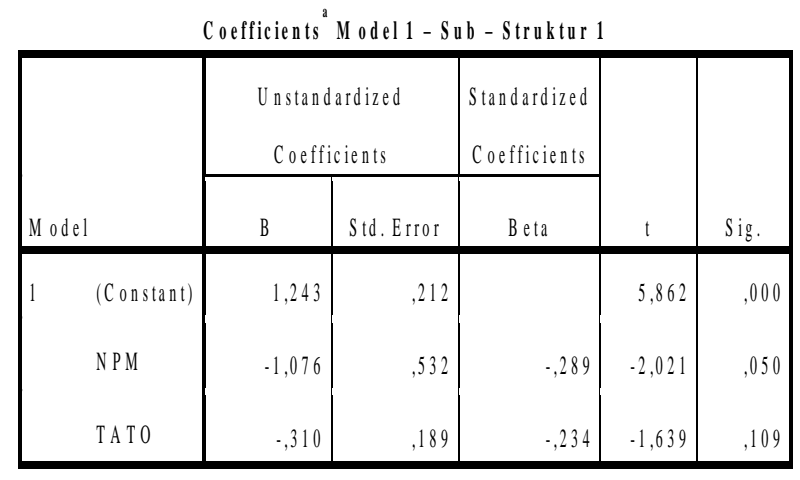

a. Dependent V ariable: DER

\section{PEMBAHASAN HASIL PENELITIAN}

Berdasarkan hasil pengujian perhitungan analisis regresi, terdapat dua variabel yang memiliki pengaruh signifikan terhadap return saham dengan nilai koefisien regresi sebesar 0,312 untuk NPM dan -0,308 untuk DER. Berdasarkan uji tersebut sehingga dapat digunakan sebagai acuan bagi manajemen dan investor dalam menentukan strategi investasinya.

Bagi pihak manajemen meningkatkan nilai perusahaan merupakan nilai yang sangat penting, nilai tersebut berdampak terhadap kelangsungan perusahaan dalam menjalankan bisnisnya. Dari hasi pengujian NPM dan DER memiliki pengaruh terhadap return saham

\section{Pengaruh Langsung NPM terhadap DER}

Berdasarkan hasil analisis koefisien jalur dapat diketahui bahwa NPM $\left(X_{1}\right)$ berpengaruh langsung negatif terhadap terhadap DER (Y) dengan memiliki pengaruh langsung negatif pada koefisien jalur $\beta_{31}=-0,289$. Hal ini berarti apabila NPM meningkat maka DER akan menurun.

\section{Pengaruh Langsung TATO terhadap DER}

Berdasarkan hasil analisis koefisien jalur dapat diketahui bahwa TATO $\left(\mathrm{X}_{2}\right)$ tidak berpengaruh langsung negatif terhadap terhadap DER (Y). Sehingga TATO tidak berpengaruh terhadap DER (Y).

\section{Pengaruh Tidak Langsung NPM terhadap Return Saham melalui DER}

Berdasarkan hasil analisis koefisien jalur dapat diketahui bahwa NPM $\left(\mathrm{X}_{1}\right)$ berpengaruh tidak langsung positif terhadap terhadap Return Saham (Z) memalui DER(Y) dengan memiliki pengaruh tidak langsung positif pada koefisien jalur $\beta_{431}=0,089$. Hal ini berarti apabila NPM meningkat maka Return Saham akan meingkat.

\section{Pengaruh Tidak Langsung TATO terhadap Return sSaham melalui DER}

Berdasarkan hasil analisis koefisien jalur dapat diketahui bahwa TATO $\left(\mathrm{X}_{2}\right)$ tidak berpengaruhterhadap terhadap Return Saham (Z) memalui DER (Y). Hal ini disebabkan perusahaan batubara membutuhkan aset yang banyak dalam memenuhi operasional perusahaan dan aset tersebut lebih banyak dibiayai oleh hutang. Sehingga TATO $\left(\mathrm{X}_{2}\right)$ tidak memiliki pengaruh terhadap Return Saham (Z) memalui DER (Y).

sehingga perusahaan harus meningkatkan NPM dan mengurangi DER. nilai NPM dipengaruhi oleh laba perusahaan, sehingga untuk meningkatkan return saham perusahaan harus meningkatkan laba dengan cara mengefisiensi biaya-biaya dalam kegiatan operasional. Selain melakukan efisiensi perusahaan juga harus meningkatkan capital perusahaan dengan cara menambah ekuitas dan mengurangi liabilitas.

Bagi Investor mendapatkan laba merupakan hal yang sangat diharapkan, oleh sebab itu, para investor selalu mencari perusahaan yang dapat memberikan keuntungan untuk menanamkan modalnya. Dari hasi pengujian NPM dan DER memiliki 
pengaruh terhadap return saham sehingga investor dapat mengetahui perusahaanperusahaan yang dapat memberikan keuntungan dengan cara melihat indikator tersebut sebagai strategi dalam menentukan keputusan untuk penanaman modal ke perusahaan.

Dari hasil penelitian menjelaskan bahwa NPM memiliki pengaruh positif dan DER memiliki pengaruh negatif terhadap return saham. Sehingga efisiensi dari operasional dan pengurangan dari hutang perusahaan akan mampu meningkatkan return saham. Oleh sebab itu, perusahaan pertambangan batubara diharapkan bisa mengurangi beban dari biaya operasional dan meningkatkan capital perusahan dengan menambah ekuitas dan mengurangi leabilitas sehingga investor akan tertarik menanamkan modal dan dapat berdampak terhadap return saham.

\section{KESIMPULAN}

1. Terdapat pengaruh langsung dan positif Antara NPM $\left(\mathrm{X}_{1}\right)$ terhadap Return Saham (Z) dengan koefisien jalur $\beta_{41}=0,312$. Dengan demikian, berarti apabila NPM pada Perusahaan pertambangan batubara Periode 2010-2014 meningkat maka Return Saham akan meningkat.

2. Tidak terdapat pengaruh langsung positif antara TATO $\left(\mathrm{X}_{2}\right)$ terhadap Return Saham (Z) disebabkan nilai koofisien jalur $\beta_{42}=$ 0,055 dan tingkat singnifikan sig $=0,707$. Dengan demikian, berarti apabila TATO pada Perusahaan pertambangan batubara Periode 2010-2014 meningkat maka Return Saham tidak akan meningkat.

3. Terdapat pengaruh langsung negatif DER (Y) terhadap Return Saham (Z) dengan koefisien jalur $\beta_{43}=-0,308$. Dengan demikian, berarti apabila DER pada Perusahaan pertambangan batubara Periode 2010-2014 menurun maka return saham akan meningkat.

4. Terdapat pengaruh langsung negatif NPM $\left(\mathrm{X}_{1}\right)$ terhadap DER $(\mathrm{Y})$ dengan koefisien jalur $\beta_{31}=-0,289$. Dengan demikian, berarti apabila NPM $\left(\mathrm{X}_{1}\right)$ pada Perusahaan pertambangan batubara Periode 20102014 meningkat maka DER (Y) akan menurun.

5. Tidak terdapat pengaruh langsung antara TATO $\left(\mathrm{X}_{2}\right)$ terhadap DER (Y) disebabkan nilai koofisien jalur $\beta_{32}=-$ 0,234 dan tingkat singnifikan sig $=0,109$. Dengan demikian, berarti apabila TATO pada Perusahaan pertambangan batubara Periode 2010-2014 meningkat maka DER tidak akan meningkat.

6. Terdapat pengaruh tidak langsung positif NPM $\left(\mathrm{X}_{1}\right)$ terhadap return saham (Z) melalui DER ( $Y$ ) dengan koefisien jalur $\beta_{431}=0,089$. Dengan demikian, berarti apabila NPM pada Perusahaan pertambangan batubara Periode 20102014 meningkat maka return saham akan meningkat.

7. Tidak terdapat pengaruh tidak langsung negatif TATO terhadap return saham (Z) melalui DER (Y). Dengan demikian berarti bahwa TATO pada Perusahaan pertambangan batubara Periode 20102014 meningkat atau menurun maka return saham tidak berpengaruh.

\section{DAFTAR PUSTAKA}

Abdulkadir Muhammad, Hukum Perusahaan Indonesia, (Bandung: Citra Aditya Bakti, 2009)

Alexandri, Moh. Benny. (2008). Manajemen Keuangan Bisnis. Cetakan Kesatu.Bandung: Alfabeta.

Bastian, Idra., Suhardjono, 2006. Akuntansi Perbankan, Buku Dua, Edisi Pertama,Salemba Empat, Jakarta.

Darmadji, Tjiptono dan Hendi M. Fakhruddin. 2001. Pasar Modal Di Indonesia: Pendekatan Tanya Jawab. Edisi Pertama. Jakarta: Salemba Empat.

Eduardus Tandelilin. (2001). Analisis Investasi dan Manajemen Portofolio. Edisi Pertama. Yogyakarta : BPFE Yogyakarta.

Fahmi, Irham, dan Hadi. 2011. Teori Portofolio dan Analisis Investasi. EdisiKedua. Bandung : Alfabeta.

Gitman, Lawrence J. 2006. Principle of Managerial Finance. Eleventh Edition. United States : Pearson.

Harahap, Sofyan Syafri. 2009. Analisis Kritis Atas Laporan Keuangan. Jakarta:RajaGrafindo Persada

Hartono, Jogiyanto. (2008). Teori Pertofolio dan Analisis Investasi.Yogyakarta:BPFE Yogyakarta.

Ivan Gumilar., \& Siti Komariah. (2011). Pengukuran Efisiensi Kinerja 
DenganMetode Stochastic Frontier Approach Pada Perbankan Syariah. Jurnal Bisnis \&Manajemen.

Jogiyanto, HM. 2010. Teori Portofolio dan Analisis Investasi. Edisi kedua.Yogyakarta:BPFE.

Martalena dan Maya Malinda. 2011. Pengantar Pasar Modal. Edisi Pertama.Yogyakarta: ANDI.

Martono, SU., Agus Hardjito. 2007. Manajemen Keuangan (Konsep dan Aplikasi), Edisi Revisi. Yogyakarta: Ekonisia.

Munawir. 2010. Analisis Laporan Keuangan, Edisi 4, Liberty, Yogyakarta.

Pasolong, Harbani. (2007). Teori Administrasi Publik.ALFABETA BANDUNG.

Riyanto, Bambang. 2008. Dasar-dasar pembelanjaan perusahaan. Yogyakarta:BPFE.

Sawidji Widoatmodjo. 2012. Cara Cepat Memulai Investasi Saham PanduanBagi Pemula. Jakarta: PT Elex Media Komputindo.

Suad Husnan, 2001, Dasar-Dasar Teori Portofolio dan Analisis Sekuritas, Edisi Ketiga, AMP YKPN, Yogyakarta.

Sugiyono, (2010), Statistika Untuk Penelitian, Alfabeta, Bandung.

Sunariyah. (2010).Pengantar Pengetahuan Pasar Modal, edisi ke enam.Yogyakarta:UPP-AMP YKPN.

Sutrisno. (2007). Manajemen Keuangan Teori, Konsep dan Aplikasi. Yogyakarta: Ekonesia.

Sutrisno, 2005. Manajemen Keuangan, Teori, Konsep, dan Aplikasi, Ekonisia,Yogyakarta.

Syamsuddin. 2009. Manajemen Keuangan Perusahaan. Jakarta: PT. Raja GrafindoPersada.

Tjiptono Darmadjidan Hendry M. Fakhruddin (2011), Pasar Modal di Indonesia,Edisi Ketiga, Penerbit Salemba Empat.

Wahyono, Hadi, 2002. Komperasi Kinerja Perusahaan Bank dan Asuransi Studi Empiris di Bursa Efek Jakarta, Jurnal riset ekonomi dan manajemen, vol. 2 No. 2, Mei 2002

www.idx.co.id

www.indonesiafinancetoday.com

www.sahamok.com

www.yahoofinance.com 